\title{
Pengaruh Motivasi Belajar dan Kemampuan Berpikir Logis Terhadap Kemampuan Membaca Pemahaman Siswa SDN Kletekan Kabupaten Ngawi
}

\author{
Etik Yuliana Prasetyaningrum \\ SDN Kletekan 1 Kecamatan Jogorogo Ngawi, Indonesia \\ e-mail: yulianaetik2@gmail.com
}

\begin{abstract}
Abstrak
Penelitian ini bertujuan untuk menganalisa dan membuktikan adanya pengaruh motivasi belajar dan kemampuan berpikir kritis terhadap kemampuan membaca pemahaman siswa. Penelitian ini merupakan penelitian kuantitatif eksperimen semu. Sampel dalam penelitian ini diambil secara acak dengan tujuan tertentu. Total sampel berjumlah 60 siswa. Teknik penghitungan menggunakan anova $2 \times 2$. Temuan dalam penelitian ini didapatkan hasil bahwa terdapat pengaruh motivasi belajar dan kemampuan berpikir logis terhadap kemampuan membaca pemahaman siswa.

Kata kunci: Motivasi belajar; berpikir logis; membaca pemahaman

\section{The Effect of Learning Motivation and Logical Thinking on Students' Reading Comprehension of SDN Kletekan, Ngawi Regency}

\begin{abstract}
This study aims to analyze and prove the influence of learning motivation and the ability to think critically on the ability to read students' understanding. This research was a quasi-experimental research of pseudo-experiment. The sample in this study was taken randomly with a specific purpose. The total sample was 60 students. The study used Anova 2x2. The findings in the study show that there is an effect of learning motivation and logical thinking ability on the students' understanding.
\end{abstract}

Keywords: Participatory method; Writing Ability; Argumentative writing

\section{Pendahuluan}

IImu pengetahuan dan teknologi sangat berperan dalam upaya meningkatkan kualitas sumber daya manusia bagi suatu bangsa. Dengan adanya peningkatan sumber daya manusia diharapkan bangsa Indonesia mampu bersaing dengan bangsa-bangsa lain. Salah satu upaya yang dapat dilakukan untuk meningkatkan sumber daya manusia adalah peningkatan mutu pendidikan, baik prestasi belajar siswa maupun kemampuan guru dalam melaksanakan proses pembelajaran. Peningkatan mutu pendidikan diarahkan untuk meningkatkan kualitas manusia seutuhnya agar memiliki daya saing dalam menghadapi tantangan global. Upaya yang dapat dilakukan untuk meningkatkan mutu pendidikan adalah perbaikan proses pembelajaran. Dalam usaha proses pembelajaran diperlukan sistem pendidikan yang berorientasi pada pemecahan masalah, kemampuan berpikir kritis, kreatif, sistematis dan logis (Depdiknas, 2003: 2).

$\mathrm{Hal}$ tersebut mengandung pengertian bahwa dalam perkembangannya, pendidikan selalu menuntut sebuah perubahan ke arah kemajuan, terutama pada aspek mutu dan kualitas yang lebih baik. Dalam dunia pendidikan, tidak hanya terpusat pada guru sebagai satu-satunya sumber ilmu, tetapi juga dari sisi peserta didik dituntut untuk 
mampu bersaing secara sehat dalam pembelajaran. Dari sinilah lahir sebuah kemampuan mendasar yang harus dimiliki peserta didik dalam menghadapi persaingan yang kian ketat. Kemampuan tersebut adalah berupa kemampuan berpikir secara ilmiah dalam bidang akademis khususnya.

Pendidikan merupakan suatu kebutuhan yang sangat penting bagi kehidupan manusia. Pendidikan adalah usaha sadar yang dilakukan oleh keluarga, masyarakat, dan pemerintah melalui kegiatan bimbingan, pengajaran, dan latihan yang berlangsung di sekolah dan di luar sekolah sepanjang hayat untuk mempersiapkan peserta didik agar dapat memainkan peranan dalam berbagai lingkungan hidup secara tepat di masa yang akan datang (Mudyaharjo, 2001: 11).

Pendidikan bukan lagi menjadi suatu kegiatan yang dilakukan karena terpaksa, tetapi dalam perkembangannya pendidikan sekarang ini menjadi suatu kebutuhan bagi setiap orang. Dengan konsep tersebut telah nampak jelas bahwa arah dan tujuan sebuah pendidikan adalah mempersiapkan peserta didik sebagai generasi penerus bangsa dalam menghadapi tantangan global. Melalui peran pendidikan, peserta didik akan dilatih secara berkesinambungan agar dapat hidup bermasyarakat dengan baik.

Untuk menyesuaikan dengan tuntutan perkembangan zaman dan peningkatan kualitas, maka berbagai perubahan dalam pendidikan perlu terus diupayakan. Perubahan tersebut antara lain tentang peran guru, materi, model pembelajaran, serta pengelolaan sistem pendidikan. Kualitas pembelajaran dapat dilihat dari aspek proses dan aspek hasil. Proses pembelajaran berhasil apabila selama kegiatan belajar mengajar siswa menunjukkan aktivitas belajar yang tinggi dan terlibat secara aktif baik fisik maupun mental. Sedangkan dari aspek hasil apabila terjadi perubahan perilaku yang positif pada siswa serta menghasilkan keluaran dengan prestasi belajar yang tinggi.

Dalam dunia pendidikan selama ini masih banyak ditemui kecenderungan memperlakukan peserta didik sebagai objek atau klien yang menerima pengetahuan, sikap, dan keterampilan. Guru lebih banyak menempatkan siswa sebagai objek, bukan sebagai subjek didik, sehingga dalam proses pembelajaran kegiatan peserta didik lebih banyak duduk, diam, mencatat, dan menghafal, sementara gurunya yang aktif mengajar.

Tidak dapat dipungkiri bahwa dewasa ini masih saja ditemui pembeajaran berpusat pada guru (teacher oriented), dan bukan pada siswa. Guru seolah-olah memegang peran utama dalam setiap kegiatan pembelajaran. Sedangkan di sisi siswa juga timbul anggapan bahwa guru adalah satu-satunya sumber ilmu dalam kegiatan beajar mengajar. Hal tersebut justru kian menambah faktor penghambat kemajuan pendidikan di Indonesia khususnya. Tidak hanya itu, hal tersebut juga bertentangan dengan fungsi serta tujuan pendidikan Indonesia.

Fungsi dan tujuan pendidikan Indonesia tercantum dalam Undang-Undang No 20 Tahun 2003 tentang Sistem Pendidikan Nasional (Sisdiknas) pasal 3 yang menyatakan bahwa pendidikan nasional berfungsi mengembangkan kemampuan dan membentuk watak serta peradaban bangsa yang bermartabat dalam rangka mencerdaskan kehidupan bangsa, bertujuan untuk berkembangnya potensi peserta didik agar menjadi manusia yang beriman dan bertakwa kepada Tuhan Yang Maha Esa, berakhlak mulia, sehat, berilmu, cakap, kreatif, mandiri dan menjadi warga negara yang demokratis serta bertangguang jawab (Arifin, 2003: 34).

Linguista Vol. 2, No. 2, Desember 2018: 87-96 
Dari fungsi dan tujuan yang tercantum di atas tampak bahwa fungsi dan tujuan utama dari sebuah pendidikan adalah mencetak generasi muda yang berkompeten di bidangnya. Pendidikan yang diselenggarakan juga membekali peserta didik dengan pendidikan religi dan pendidikan karakter yang berfungsi dalam membentuk kepribadian peserta didik yang beriman, mandiri, cakap serta penuh kreativitas dalam mengembangkan segala potensi yang dimilikinya.

Adanya fungsi dan tujuan pendidikan yang termuat dalam peraturan perundangundangan maka diharapkan peranan pendidikan di Indonesia dapat menciptakan generasi masa depan yang berkualitas. Namun, pada kenyataannya tujuan pendidikan di Indonesia belum bisa mencapai target sesuai dengan apa yang diharapkan. Karena banyak tantangan di era globalisasi, sehingga yang bisa bertahan hanyalah mereka yang memiliki kemampuan lebih kritis, kreatif, dan profesional.

Dalam dunia pendidikan, pembelajaran bahasa Indonesia menjadi salah satu mata pelajaran wajib di setiap jenjang pendidikan. Bahasa Indonesia sebagai ilmu wajib dari segala bidang ilmu pendidikan merupakan hal yang sangat penting untuk diketahui. Namun selama ini proses pembelajaran bahasa Indonesia di setiap tingkat pendidikan hanya terbatas pada peningkatan kemampuan kognitif saja. Padahal ciri khusus pembelajaran bahasa Indonesia adalah penekanan pada proses deduktif yang memerlukan penalaran logis. Selain itu bahasa Indonesia merupakan proses yang aktif, dinamik dan generatif. Kegiatan pembelajaran bahasa Indonesia memberikan sumbangan yang penting kepada peserta didik dalam pengembangan nalar, berpikir logis, sistematik, kritis, kreatif, dan bersikap obyektif serta terbuka dalam menghadapi berbagai permasalahan.

Pembinaan dan pengembangan bahasa Indonesia secara baik dan benar menjadi prioritas, sehingga peningkatan, pengembangan dan pelestarian bahasa Indonesia mencakup semua lembaga pendidikan dan menjangkau masyarakat luas. Sekolah sebagai lembaga pendidikan formal, dijadikan tempat yang mempunyai peran penting dan strategis untuk melaksanakan tugas tersebut. Namun yang perlu dicermati, semakin pentingnya kedudukan bahasa Indonesia dan semakin optimalnya intensitas pembelajaran bahasa, pada kenyataannya tidak cukup berhasil untuk mencetak generasi yang cinta dan terampil dengan penggunaan bahasa Indonesia yang baik dan benar (Sudarma, 2012: 2).

Pentingnya pembelajaran bahasa Indonesia bisa dilihat dari manfaat dan kegunaan bahasa Indonesia dalam kehidupan sehari-hari, juga bagi perkembangan ilmu pengetahuan. Oleh karena itu penyempurnaan kurikulum terus dilakukan Depdiknas, antara lain dengan memasukkan kemampuan berpikir logis, analitis, sistematis, kritis, dan kreatif sebagai standar kompetensi mata pelajaran bahasa Indonesia yang termuat dalam kurikulum 2006. Berangkat dari persepsi terebut mata pelajaran bahasa Indonesia diberikan kepada semua peerta didik sejak dari sekolah dasar (SD) untuk membekali siswa agar mempunyai kemampuan berpikir logis, analitis, sistematis, kritis, kreatif, serta memiliki kemampuan bekerja sama.

Untuk mencapai tujuan tersebut memang tidaklah mudah. Berbagai persepsi awal yang dimiliki siswa terhadap pelajaran bahasa Indonesia, telah membentuk sikap yang beragam, sehingga membuat proses pembelajaran bahasa Indonesia tidak berjalan efektif. Menurut Uno (2010: 106) karakter siswa merupakan salah satu variabel dari kondisi pengajaran. Variabel ini didefinisikan sebagai aspek-apek atau kualitas

Pengaruh Motivasi Belajar dan Kemampuan Berpikir Logis... (Etik Yuliana Prasetyaningrum) 
perseorangan siswa. Aspek-aspek ini bisa berupa bakat, minat, sikap, motivasi, gaya belajar, disiplin belajar, kemampuan berpikir, dan kemampuan awal (hasil belajar yang telah dimilikinya). Diantara aspek tersebut, peneliti mengambil fokus pada motivasi belajar dan kemampuan berpikir logis siswa.

Pembelajaran bahasa Indonesia merupakan pelajaran yang dianggap sepele dan mudah oleh sebagian besar siswa. Namun pada kenyataannya banyak siswa yang justru tidak lulus ujian dikarenakan nilai pelajaran bahasa Indonesia yang buruk. Para siswa lebih sulit untuk menerka dan memahami isi dari sebuah bacaan. Soal-soal dan pertanyaan yang berkaitan dengan bacaan menjadi momok tersendiri bagi para siswa untuk mata pelajaran bahasa Indonesia.

Pada dasarnya membaca merupakan salah satu keterampilan berbahasa yang sangat penting disamping tiga keterampi-lan bahasa lainnya (Somadayo, 2011: 1). Hal ini dikarenakan membaca merupakan sarana untuk mempe-lajari dunia, memperluas pengetahuan dan menggali pesan-pesan dalam bentuk tulisan. Dengan memba $\neg$ ca, seseorang dapat bersantai, beinteraksi dengan pikiran, memperoleh informasi dan meningkatkan ilmu pengetahuan (Somadayo, 2011: 2). Perkembangan ilmu pengetahuan dan teknologi menuntut terciptanya masayarakat yang gemar membaca. Hal ini dimaksudkan dengan bertambahnya wawasan dan penge-tahuan masyarakat membantu masayarakat dalam menjawab tantangan hidup pada masa mendatang (Rahim, 2005: 1).

Hal tersebut dapat diartikan bahwasanya peran pendidikan sangatlah penting. Di dalam pendidikan terdapat pembelajaran yang mngarahkan peserta didik ke arah yang lebih baik. Dengan kata lain, proses pembelajaran dalam dunia pedidikan haruslah mampu mencetak generasi yang mempunyai keterampilan yang menunjang di era globalisasi sekarang ini.

Dalam kegiatan belajar mengajar, keterampilan membaca bukanlah seseuatu yang mudah untuk dipelajari atau bahkan diajarkan kepada setiap peserta didik. Mengingat dan memperhatikan kesenjangan kemampuan dalam diri siswa yang berbeda-beda, maka pembelajaran membaca menjadi sesuatu yang menjatuhkan nilai belajar siswa dalam ranah akademiknya. Untuk itu, di dalam pembelajaran bahasa Indonesia kemampuan membaca menjadi prioritas utama sebagai suatu keterampilan yang harus dimiliki settiap siswa.

Pengembangan kemampuan membaca pemahaman yang dimulai sejak dini akan membantu ter-lakasananya proses pembelajaran yang sukses. Anak anak yang tidak memahami pentingnya belajar membaca tidak akan termotivasi untuk belajar (Rahim, 2005:1). Disampaikan pula oleh Chall (dalam Santrock (2007: 421)) bahwa siswa yang berada di grade empat yang belum mampu menguasai keahlian membaca akan mengalami kesulitan serius di bidang akademik. Hal tersebut menjadi salah satu penyebab kurangnya motivasi belajar siswa terhadap pembelajaran bahasa Indonesia. Tidak dapat dipungkiri bahwa selain hal tersebut, ada faktor internal yang mempengaruhi hasil belajar siswa yang kurang optimal, yaitu motivasi belajar.

Motivasi belajar merupakan suatu kekuatan, tenaga, atau daya, baik yang datang dari dalam maupun dari luar individu, yang mendorong individu tersebut untuk belajar. Artinya motivasi belajar adalah dorongan niat yang menggerakkan dan mengarahkan siswa dalam belajar. Motivasi belajar juga dapat meningkatkan rasa ingin tahu siswa untuk mempelajari sesuatu hal yang baru. Tercapainya hasil belajar siswa juga 
tergantung pada tinggi rendahnya motivasi belajar yang dimilikinya. Jika motivasi belajar siswa rendah, maka dipastikan akan berdampak pada rendahnya nilai akademiknya pula (Dalyono, 2009: 53-54).

Motivasi belajar sebagai sebuah dasar utama guna mendorong peserta didik semangat dalam kegiatan pmbelajaran. Tidak dapat dipungkiri bahwa motivasi belajar sebagai faktor internal dalam diri seseorang, ikut mempengaruhi terhadap hasil belajar yang dicapai peserta didik. Rendahnya motivasi belajar siswa tersebut akan berdampak pada hasil belajar yang kurang optimal dan kurang berkembangnya kemampuankemampuan yang dimiliki siswa setelah melakukan proses pembelajaran di sekolah, sehingga motivasi belajar sangatlah penting dalam mencapai keberhasilan pembelajaran.

Dalam kaitannya dengan belajar, motivasi sangat erat hubungannya dengan kebutuhan aktualisasi diri sehingga motivasi paling besar pengaruhnya pada kegiatan belajar siswa. Apabila tidak ada motivasi belajar dalam diri siswa, maka akan menimbulkan rasa malas untuk belajar baik dalam mengikuti proses belajar mengajar maupun mengerjakan tugas-tugas individu dari guru. Orang yang mempunyai motivasi yang tinggi dalam belajar maka akan timbul minat yang besar dalam mengerjakan tugas, membangun sikap dan kebiasaan belajar yang sehat melalui penyusunan jadwal belajar dan melaksanakannya dengan tekun.

Motivasi mempunyai fungsi yang sangat penting dalam belajar siswa, karena motivasi akan menentukan intensitas usaha belajar yang dilakukan oleh siswa. Para siswa yang memiliki motivasi yang tinggi, belajarnya lebih baik dibandingkan dengan para siswa yang memiliki motivasi rendah. Hal ini berarti siswa yang memiliki motivasi belajar tinggi akan tekun dalam belajar dan terus belajar secara kontinyu tanpa mengenal putus asa serta dapat mengesampingkan hal-hal yang dapat mengganggu kegiatan belajar, khususnya dalam pembelajaran bahasa Indonesia.

Proses pembelajaran bahasa Indonesia pada umumnya tidak hanya mendengar dan mencatat, akan tetapi menyimak, membaca, berbicara dan menulis. Keempat aktivitas dalam pembelajaran bahasa Indonesia tersebut menuntut para siswa untuk berpikir dan membangun suasana komunikatif. Proses tersebut diarahkan pada peningkatan kemampuan berpikr logis siswa, sehingga siswa mampu memperoleh pengetahuan yang mereka konstruksi sendiri. Proses berpikir selalu terjadi dalam setiap aktivitas manusia yang bertujuan untuk memecahkan masalah, membuat keputusan, maupun untuk mencari pemahaman. Melalui berpikir, manusia mampu memahami segala hal yang dihadapinya dalam kehidupan. Banyaknya asumsi mengenai proses berpikir itu sendiri juga pada akhirnya belum mampu untuk mewujudkan tujuan dari pembelajaran selama ini.

Kemampuan berpikir kritis dan logis sangat diperlukan oleh siswa mengingat bahwa dewasa ini ilmu pengetahuan dan teknologi berkembang sangat pesat dan memungkinkan siapa saja bisa memperolah informasi secara cepat dan mudah dengan melimpah dari berbagai sumber dan tempat manapun di dunia. Hal ini mengakibatkan cepatnya perubahan tatanan hidup serta perubahan global dalam kehidupan. Jika para siswa tidak dibekali dengan kemampuan berpikir logis maka mereka tidak akan mampu mengolah, menilai dan megambil informasi yang dibutuhkannya untuk menghadapi tantangan tersebut. Oleh karena itu, kemampuan berpikir logis merupakan kemampuan yang sangat penting dalam proses belajar bahasa Indonesia.

Pengaruh Motivasi Belajar dan Kemampuan Berpikir Logis... (Etik Yuliana Prasetyaningrum) 
Dalam proses belajar mengajar, kemampuan berpikir yang sesuai dengan tuntutan kurikulum, dan mampu dijadikan faktor penunjang dalam keberhasilan siswa menyerap materi pelajaran salah satunya adalah kemampuan berpikir logis. Menurut Yulianti (2009: 16) berpikir logis merupakan kegiatan berpikir yang tinggi, yang meliputi kegiatan menganalisis, mensintesis, mengenal permasalahan dan cara memecahkannya, menyimpulkan serta mengevaluasi. Kemampuan berpikir logis sangat penting untuk mengembangkan kemampuan akademik seseorang dalam hal ini adalah peserta didik.

Peningkatan kemampuan berpikir logis dalam kegiatan formal dapat dikembangkan melalui pembelajaran membaca pemahaman dalam mata pelajaran bahasa Indonesia. Menurut Somadyo (2010: 10) membaca pemahaman merupakan proses pemerolehan makna secara aktif dengan melibatkan pengetahuan dan pengalaman yang dimiliki oleh pembaca serta dihubungkan dengan isi bacaan.

\section{Metode Penelitian}

Penelitian ini dilaksanakan di SDN Kletekan Kabupaten Ngawi selama 1 (satu) semester di semester gasal tahun pelajaran 2016/2017. Penelitian ini termasuk ke dalam jenis penelitian kuantitatif eksperimen semu. Desain penelitian menggunakan Anava 2x2. Populasi dalam penelitian ini adalah seluruh siswa SDN Kletekan 1 dan SDN Kletekan 2. Sampel dalam penelitian ini sebanyak 60 orang siswa. Teknik pengumpulan data dalam penelitian ini ada 2, yaitu dengan angket dan tes berskala Liekert

\section{Hasil dan Pembahasan \\ Pengaruh Motivasi Belajar Terhadap Kemampuan Membaca Pemahaman Siswa}

Dari pengujian yang telah dilakukan menggunakan uji Anova, didapatkan hasil nilai signifikansi pada variabel motivasi belajar sebesar $0,000<0,05$. Hal tersebut mengandung pengertian bahwa $\mathrm{H} 1 \mathrm{~A}$ diterima. Atau dapat dikatakan bahwa terdapat pengaruh motivasi belajar terhadap kemampuan membaca pemahaman siswa.

Hal tersebut sesuai dengan fakta motivasi dipandang sebagai dorongan mental yang menggerakkan dan pengarahkan perilaku manusia, termasuk perilaku belajar. Artinya, motivasi sebagai faktor internal seseorang yang mendorong dan membangkitkan sebuah semangat dalam belajar. Apabila seseorang telah memiliki dorongan yang kuat terhadap sesuatu hal, maka individu tersebut akan terus berusaha meraih hasil yang maksimal. Begitu pula dalam kegiatan pembelajaran, setiap siswa yang telah memiliki motivasi belajar yang tinggi, maka siswa tersebut akan bersemangat dalam pembelajaran, sehingga materi pembelajaran yang ada akan mudah terserap dan siswa tersebut dipastikan akan memiliki kemampuan intelektual yang tinggi pula.

Pembelajaran bahasa Indonesia identik dengan persoalan memahami sebuah teks bacaan, sehingga setiap siswa dituntut untuk memiliki kemampuan membaca pemahaman yang tinggi pula. Dalam kaitannya, motivasi belajar dipandang sebagai modal utama dorongan individu yang mempengaruhi semangat belajar. Apabila siswa telah termotivasi untuk belajar, maka siswa tersebut akan senantiasa memanfaatkan waktu dengan membaca, sehingga kemampuan membaca pemahamannya juga akan meningkat.

Dari hasil temuan ini dapat ditarik kesimpulan bahwa motivasi sangat berperan dalam mengembangkan potensi-potensi dalam diri seseorang. Sesorang yang memiliki 
motivasi tinggi akan cenderung menekuni suatu pekerjaan hingga mencapai hasil yang memuaskan. Dalam implementasinya di pembelajaran, motivasi berguna sebagai dorogan yang membangun semangat belajar siswa. Oleh karena itu akan terdapat perbedaan yang nyata dari hasil belajar antara siswa yang memiliki motivasi tinggi dengan siswa yang memiliki motivasi belajara rendah.

Berdasarkan pengujian hipotesis pertama yang menyatakan bahwa terdapat pengaruh motivasi belajar terhadap kemampuan membaca pemahaman siswa telah teruji kebenarannya. Dari hasil penghitungan ANAVA dua jalan diperoleh nilai sig $\mathrm{F}$ sebesar $0,000<0,05$ yang berarti $\mathrm{H} 1 \mathrm{~A}$ diterima. Hal tersebut mengandung pengertian bahwa motivasi belajar berpengaruh terhadap kemampuan membaca pemahaman siswa. Atau terdapat perbedaan kemampuan membaca pemahaman siswa yang memiliki motivasi belajar tinggi dengan siswa yang memiliki motivasi belajar rendah.

Hasil pengujian hipotesis pertama yang telah teruji kebenarannya ini berbanding lurus dengan hasil pengujian pada penelitian yang telah dilakukan sebelumnya. Pada hasil penelitian (Dewi, 2007) yang didapatkan dari jurnal elektronik tersebut diketahui bahwa terdapat perbedaan hasil belajar antara siswa yang memiliki motivasi tinggi dengan siswa yang memiliki motivasi rendah.

Hasil perbandingan penelitian menunjukkan adanya pengaruh motivasi belajar terhadap kemampuan siswa. Sesuai dengan teori yang dikemukakan oleh Surya (2004: 62) yang menyatakan bahwa motivasi belajar merupakan proses yang mendorong seseorang untuk melakukan sesuatu. Seseorang yang termotivasi belajar menunjukkan upaya yang sungguh-sungguh untuk berpikir dan memusatkan perhatian, serta merencanakan dan melaksanakan berbagai kegiatan yang menunjang belajar.

Dari temuan ini dapat dipahami bahwa motivasi belajar sebagai suatu daya penggerak bagi seseorang dalam melakukan sesuatu. Tanpa adanya dorongan kuat berupa motivasi belajar, maka mustahil jika pembelajaran dapat mencapai hasil yang optimal. Karena pada hakikatnya, pembelajaran harus berjalan dua arah, yaitu dari dalam diri peserta didik dan dari luar berupa lingkungan belajar. Oleh karena itu siswa yang memiliki motivasi belajar tinggi akan menunjukkan keampuan membaca pemahaman yang tinggi pula dibandingkan dnegan siswa yang memiliki motivasi belajar rendah.

\section{Pengaruh Kemampuan Berpikir Logis Terhadap Kemampuan Membaca Pemahaman}

Berdasarkan pengujian yang telah dilakukan, diperoleh hasil nilai signifikansi kemampuan berpikir logis sebesar 0,000 $<0,05$. Hal ini mengandung pengertian bahwa $\mathrm{H} 1 \mathrm{~B}$ diterima. Atau terdapat pengaruh kemampuan berpikir logis terhadap kemampuan membaca pemahaman siswa.

Membaca adalah kemampuan yang kompleks, karena pembaca tidak hanya memandangi lambang-lambang tertulis semata, melainkan berupaya memahami makna lambang-lambang tertulis tersebut. Selain itu membaca juga merupakan aktivitas rumit yang melibatkan aktivitas visual, berpikir, psikolinguistik, dan metakognitif.

Selaras dengan fakta tersebut, dalam kegiatan membaca diperlukan adanya pemahaman konkret terhadap sesuatu hal berupa akna yang tersirat maupun yang tersirat. Dalam kaitannya dengan kemampuan berpikir logis, kegiatan membaca hanya akan menjadi sebuah aktvitas yang sia-sia apabila tidak diimbangi dengan kemampuan berpikir secara rasional.

Pengaruh Motivasi Belajar dan Kemampuan Berpikir Logis... (Etik Yuliana Prasetyaningrum) 
Dalam kegiatan berpikir logis, terdapat sebuah aktivitas transfer data dari apa yang dilihat oleh mata dan kemudian diolah di dalam otak manusia. Proses perpindahan dan pengolahan bahan di dalam otak tersebut dinamakan proses transformasi pikiran. Di dalam pikiran, segala hal yang berkaitan dengan informasi akan diolah secara sempurna. Maka kemampuan berpikir logis sangat diperlukan dalam kegiatan pembelajaran seperti membaca pemahaman. Dari hasil temuan ini dapat disintesiskan bahwa semakin tinggi kemampuan berpikir logis seseorang, akan berbanding lurus dengan kemampuan membaca pemahaman seseorang

Berdasarkan pengujian hipotesis kedua yang menyatakan bahwa terdapat pengaruh kemampuan berpikir logis terhadap kemampuan membaca pemahaman siswa telah teruji kebenarannya. Dari hasil penghitungan ANAVA dua jalan diperoleh nilai sig $F$ sebesar $0,000<0,05$ yang berarti $\mathrm{H} 1 \mathrm{~B}$ diterima. Hal tersebut mengandung pengertian bahwa kemampuan berpikir logis berpengaruh terhadap kemampuan membaca pemahaman siswa. Atau terdapat perbedaan kemampuan membaca pemahaman siswa yang memiliki kemampuan berpikir logis tinggi dengan siswa yang memiliki kemampuan berpikir logis rendah.

Hasil pengujian hipotesis kedua yang telah teruji kebenarannya ini berbanding lurus dengan hasil pengujian pada penelitian yang telah dilakukan sebelumnya. Pada hasil penelitian (Kusuma, 2005) yang didapatkan dari jurnal elektronik tersebut diketahui bahwa terdapat perbedaan prestasi belajar antara siswa yang memiliki kemampuan berpikir logis tinggi dengan siswa yang memiliki kemampuan berpikir logis rendah.

Kesamaan hasil pengujian hipotesis dalam penelitian ini dengan penelitian yang telah dilakukan sebelumnya lebih dikarenakan adanya faktor perbedaan tingkat kemampuan berpikir logis siswa. Pada kelompok siswa yang memiliki kemampuan berpikir logis tinggi menunjukkan perolehan nilai kemampuan akademik yang tinggi dibandingkan dengan kelompoksiswa yang memiliki kemampuan berpikir logis rendah.

Kemampuan berpikir logis sebagai sarana pengolahan permasalahan dan materi yang dipelajari selama pembelajaran berlangsung. Apabila siswa telah memiliki modal berupa kemampuan berpikir logis tinggi, maka siswa tersebut dipastikan akan dapat menyimpulkan jawaban dan solusi dari setiap permasalahan yang ada terkait materi pelajaran. Hal tersebut diperkuat dengan teori yang dikemukakan oleh Mundiri (1996: 15) yang menyatakan bahwa logika membantu manusia berpikir lurus, efisien, tepat, dan teratur untuk mendapatkan kebenaran dan menghindari kesalahan. Keseluruhan informasi merupakan suatu sistem yang bersifat logis, karena itu science tidak melepaskan kemungkinan terhadap logika. Hal tersebut mengandung arti bahwa manusia menggunakan logika dalam proses berpikir, bertindak, dan bersikap objektif. Bila seseorang memiliki pikiran yang tepat sesuai dengan logika maka dapat dikatatan orang tersebut memiliki pemikiran yang logis.

\section{Interaksi Antara Motivasi Belajar dan Kemampuan Berpikir Logis Terhadap Kemampuan Membaca Pemahaman Siswa}

Berdasarkan pengujian analisis variansi dua jalan diperoleh nilai signifikansi sebesar 0,000<0,05, H1AB diterima. Artinya terdapat interaksi antara motivasi belajar dan kemampuan berpikir logis terhadap kemampuan membaca pemahaman siswa.

Dari pengujian terhadap hipotesis ketiga diketahui bahwa nilai rata-rata motivasi dan kemampuan berpikir logis terdiri dari beberapa bagian. Pertama, nilai rata-rata siswa 
yang memiliki motivasi tinggi dan kemampuan berpikir logis tinggi adalah sebesar 121,4. Kedua, nilai rata-rata siswa yang memiliki motivasi tinggi dan kemampuan berpikir logis rendah adalah sebesar 90 . Ketiga, nilai rata-rata siswa yang memiliki motivasi rendah dan kemampuan berpikir logis tinggi adalah sebesar 104,762. Keempat, nilai rata-rata siswa yang memiliki motivasi rendah dan kemampuan berpikir logis rendah adalah sebesar 87.

Berdasarkan data tersebut dapat disimpulkan bahwa terdapat interaksi antara motivasi belajar dan kemampuan berpikir logis terhadap kemampuan membaca pemahaman siswa. Temuan hasil penelitian ini sesuai dengan teori-teori yang dikemukakan para ahli. Sesuai dengan fakta di lapangan, siswa yang memiliki motivasi belajar yang tinggi mempunyai semangat belajar yang tinggi pula. Ditunjang dengan kemampuan berpikir logis yang tinggi sebagai stimulus penggerak dalam melakukan sesuatu dengan sebaik mungkin hingga mencapai hasil yang maksimal

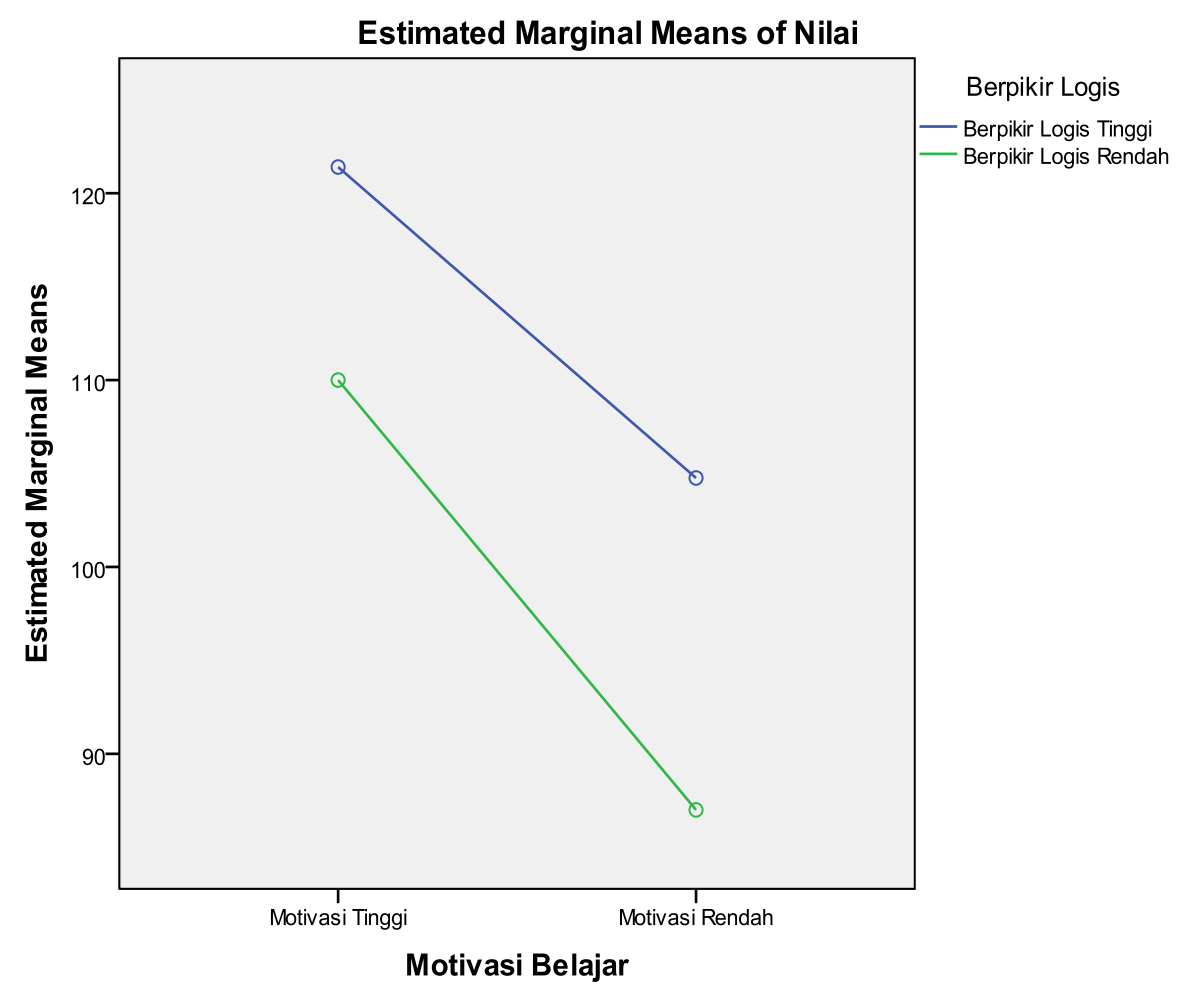

Grafik 1. Pola Interaksi Antara Motivasi Belajar dan Kemampuan Berpikir Logis Terhadap Kemampuan Membaca Pemahaman

Berdasarkan grafik di atas tampaklah bahwa nilai kemampuan membaca pemahaman siswa yang memiliki motivasi belajar tinggi dan memiliki kemampuan berpikir logis tinggi lebih tinggi dibandingkan dengan yang memiliki motivasi rendah dan memiliki kemampuan berpikir logis rendah.

Berpedoman pada hasil temuan ini, diketahui bahwa tidak hanya kemampuan berpikir saja yang dapat mempengaruhi kemampuan siswa, tetapi juga faktor motivasi belajar sebagai pendorong yang ikut menunjang kemampuan membaca pemahaman siswa. Pembelajaran bahasa Indonesia memerlukan kemampuan berpikir yang tajam dalam menafsirkan hal yang tersirat maupun yang tersurat dari sebuah bacaan. Hal 
tersebut harus ditunjang oleh adanya faktor lain yaitu motivasi belajar dan kemampuan berpikir logis.

Berdasarkan pengujian hipotesis ketiga yang menyatakan bahwa terdapat interaksi antara motivasi belajar dan kemampuan berpikir logis terhadap kemampuan membaca pemahaman siswa telah teruji kebenarannya. Dari hasil penghitungan ANAVA dua jalan diperoleh nilai sig $F$ sebesar $0,000<0,05$ yang berarti $\mathrm{H} 1 \mathrm{AB}$ diterima. Hal tersebut mengandung pengertian bahwa terdapat interaksi antara motivasi belajar dan kemampuan berpikir logis terhadap kemampuan membaca pemahaman siswa.

Dalam setiap proses pembelajaran, dipastikan adanya perbedaan tingkat kemampuan membaca pemahaman siswa. Perbedaan tersebut disebabkan banyak faktor, diantaranya motivasi belajar dan kemampuan berpikir logis. Pembelajaran bahasa Indonesia yang lekat dengan unsur bacaan menuntut siswa untuk mampu menganalisa setiap permasalahan yang terseirat dalam bacaan tersebut. Tinggi rendahnya kemampuan berpikir logis siswa dalam mengolah informasi terkait esensi sebuah bacaan tentunya juga akan berdampak terhadap kemampuan membaca pemahamannya.

Namun di sisi lain yang ikut mempengaruhi kemampuan membaca pemahaman siswa adalah terletak pada semangat belajar siswa, dalam hal ini adalah motivasi belajar. Seseorang yang memiliki motivasi tinggi akan mampu memahami isi dari sebuah bacaan yang ada, sehingga nilai akademik pada mata pelajaran bahasa Indonesia juga akan tinggi.

Jika dikaitkan dengan kemampuan berpikir logis, daya dorong siswa yang berupa motivasi belajar akan menjadi tenaga pendorong yang kuat. Di sisi lain kemampuan berpikir logis tinggi menjadi pusat pengolahan segala informasi dan permasalahan yang ada sehingga siswa akan mampu menemukan detail jawaban dan solusi atas permasalahan yang ada.

\section{Kesimpulan}

Dari penelitian yang telah dilakukan, dapat ditarik kesimpulan bahwa; (1) terdapat pengaruh motivasi belajar terhadap kemampuan membaca pemahaman siswa; (2) terdapat pengaruh kemampuan berpikir logisterhadap kemampuan membaca pemahaman siswa; dan (3) terdapat interaksi antara motivasi belajar dan kemampuan berpikir logisterhadap kemampuan membaca pemahaman siswa.

\section{Daftar Pustaka}

Hamalik, Oemar. 2004. Proses Belajar Mengajar. Jakarta: Bumi Aksara.

Hamzah, Uno. 2008. Teori Motivasi dan Pengukurannya Analisis di Bidang Pendidikan. Jakarta: Bumi Aksara.

Isbandi, Rukminto. 2000. Psikologi Pekerjaan Sosial dan IImu Kesejahteraan Sosial (Dasar-Dasar Pemikiran). Jakarta: PT. Raja Grafindo.

Jones, Derek llewellyn. 2012. Panduan Lengkap Tentang Kesehatan, Kebidanan dan Kandungan. Jakarta: Delaprasta. 